\title{
Pharmacological Induction of Heme Oxygenase-1 Reduces KB Cell Viability: Role of Carbon Monoxide
}

\author{
Russo Alessandra ${ }^{1}$, Berretta Massimiliano ${ }^{2,3}$, Cardile Venera ${ }^{4}$, Lombardo Laura ${ }^{4}$, Vanella Luca ${ }^{1}$, Troncoso Nicolas ${ }^{5}$, Garbarino Juan ${ }^{6}$, Ignazio Barbagallo ${ }^{1,3}$ \\ and Li Volti Giovanni ${ }^{3,7 *}$ \\ ${ }^{1}$ Department of Drug Sciences, University of Catania, Italy
}

${ }^{2}$ Department of Medical Oncology, National Cancer Institute IRCCS, Italy

${ }^{3}$ EuroMediterranean Institute of Science and Technology, Palermo, Italy

${ }^{4}$ Department of Biomedical Sciences, University of Catania, Catania, Italy

${ }^{5}$ Fundaciòn Chile, Area Agroindustrias, Santiago, Chile

${ }^{6}$ Department of Chemistry, University T.F. Santa Maria, Chile

${ }^{7}$ Department of Clinical and Molecular Biomedicine, University of Catania, Catania, Italy

*Corresponding author: Giovanni Li Volti, Department of Clinical and Molecular Biomedicine, University of Catania, Viale Andrea Doria, 6 , 95125 Catania, Italy, Tel: +39-095-7384081; Fax: +39-095-7384220; E-mail: livolti@unict.it

Recieved date: Dec 11, 2013, Accepted date: April 10, 2014, Published date: April 16, 2014

Copyright: (c) 2014 Alessandra R, et al. This is an open-access article distributed under the terms of the Creative Commons Attribution License, which permits unrestricted use, distribution, and reproduction in any medium, provided the original author and source are credited.

\begin{abstract}
Heme oxygenase-1 (Hmox1) catalyzes the rate-limiting step in heme degradation, releasing iron, carbon monoxide (CO), and biliverdin. The aim of the present study was to investigate Hmox1 as a possible mechanism underlying propolis cytotoxic effects in KB cells. Cells were cultured for 24,48 and 72 hours and treated with propolis or $\mathrm{SnCl}_{2}$, known inducers of $\mathrm{Hmox} 1$ protein expression and activity. Propolis and $\mathrm{SnCl}_{2}$ treatments decreased cell viability and induced Hmox1 expression. Furthermore, propolis increased LDH release and decreased dramatically reactive oxygen species (ROS) formation. Toxic effects of both propolis and $\mathrm{SnCl}_{2} \mathrm{Were}$ reversed by tin-mesoporphirin (SnMP), a Hmox activity inhibitor. No significant effect was observed on p21 expression following propolis treatment. By contrast, $\mathrm{SnCl}_{2}$ decreased $\mathrm{ROS}$ formation and increased p21 expression but did not affect LDH release. These results were further confirmed by the use of CO releasing molecule (tricarbonyldichlororuthenium dimer (II)) (CORM-II) treatment (10-40 $\mu \mathrm{M}$ ). Our results suggest that propolis mediates $\mathrm{KB}$ cell cytotoxicity, in part by Hmox1 induction, and that $\mathrm{KB}$ cells are very sensitive to $\mathrm{Hmox} 1 \mathrm{derived} \mathrm{CO}$, a property that may be relevant for oral squamous cell carcinoma therapy.
\end{abstract}

Keywords: Squamous cell carcinoma; Hmox1 protein; Heme degradation; Lymphosarcoma

\section{Introduction}

Squamous cell carcinoma (SCC) is the most frequent malignant tumor of the oral cavity with poor clinical outcome. Over 197,000 deaths occur per year worldwide, of which $74 \%$ are in developing countries [1]. Among many risk factors, tobacco and alcohol are prevalent in the development of oral carcinogenesis, being involved in $>75 \%$ of oral cancers in the USA, France and Italy [2,3]. Important advances have been made during the last decade in molecular understanding of oral cancer and its application for early and sensitive diagnosis, effective treatment and improved prognosis. In previous studies the potential of using heme oxygenase-1 (Hmox1) and p21, a well-known inhibitor of cellular proliferation, as markers for clinicopathological features was reported [4,5]. Furthermore, a relation between malignant behavior and alteration of Hmox has been demonstrated. Elevated Hmox activity was found in renal adenocarcinoma, compared with juxtatumor or normal renal tissues and this elevation was attributed solely to Hmox1 gene expression [6]. In addition, increased expression of Hmoxl was detected in lymphosarcoma [7], benign prostatic hyperplesia and prostate cancer and hepatoma [8,9]. In human gliomas, Hmoxl may be a useful marker for macrophage infiltration as well as neovascularization [10]. In this regard, Abraham et al. showed that over-expression of Hmox1 gene potentiates pancreatic cancer aggressiveness, by increasing tumor growth, angiogenesis and metastasis and that inhibition of Hmox system may be of useful benefit for the future treatment of the disease [11]. However, the precise molecular signals by which Hmox1 regulates cellular proliferation in SCC have not been investigated so far.

Hmox isoforms catalyze the conversion of heme to carbon monoxide (CO) and biliverdin, with a concurrent release of iron, which can drive the synthesis of ferritin for iron sequestration [12]. To date, two Hmox isoforms have been shown to be catalytically active in heme degradation, and each is encoded by a different gene $[13,14]$. Hmox-2 is constitutively expressed in blood vessels, endothelium, testis and most other tissues and its levels are relatively unaffected by factors inducing Hmox1 [15]. Hmoxl is expressed under basal conditions and its expression and activity can be induced by oxidative stress-causing agents, heavy metals and polyphenolic compounds such as rosolic acid, caffeic acid phenethyl ester (CAPE) [16-20]. This is an active compound of propolis, a natural honeybee product exhibiting a spectrum of biological activities, including anti-microbial, anti- 
inflammatory, anti-oxidant and anti-tumoral actions [21-23]. Most of these properties have been attributed, in part, to CAPE anti-oxidant activity $[22,24,25]$, which is primarily due to the phenolic hydroxyl groups being able to furnish hydrogen atoms in scavenging reactive oxygen species (ROS). It has been suggested that ROS may play a key role in signal transduction and activation of specific genes promoting cancer cell proliferation [26]. As such, scavenging ROS with phenolic phytochemicals should inhibit these cellular processes and thus cancer cell proliferation. However, we and others [18,27] suggested a potential novel aspect in the mode of action of phenolic phytochemicals; that is, the ultimate stimulation of Hmox1 pathway is likely to account for the established and powerful antioxidant/antiinflammatory properties of these polyphenols. Our recent studies [28] evidenced that $\mathrm{KB}$ cells are more sensitive to the Chilean propolis ethanolic extract, containing a high concentration of CAPE and exhibiting interesting antioxidant activity, when compared to others tumor cell lines such as Caco-2 and DU-145. In addition, it has been reported that other oral tumor cell lines are more sensitive to CAPE treatment when compared to non tumoral cell lines [29].

Therefore, the present study was designed to evaluate the effect of Chilean propolis on the SCC Hmox system and how this may impact on ROS formation and molecular mechanism leading to cellular proliferation mechanisms.

\section{Materials and Methods}

\section{Materials}

Cell culture medium and sera were obtained from Life Technologies Ltd. (Milano, Italy). Monoclonal Hmoxl and Hmox-2 antibodies were from Stressgen Biotechnologies (Victoria, BC, Canada). Secondary horseradish peroxidase-conjugated anti-mouse antibody and p21 monoclonal antibody were from Santa Cruz Biotechnology (Santa Cruz, CA, USA). The ECL (enhanced chemiluminescence) system for developing immunoblots and nitrocellulose membranes was purchased from Amersham (Milano, Italy). Tricarbonyldichlororuthenium was purchased from Sigm-Aldrich (Milan, Italy). All other chemicals were purchased from Merck (Frankfurt, Germany).

\section{Propolis sample}

Propolis ethanolic extract was provided by NATURANDESCHILE. Propolis sample was collected at San Vicente de Tagua-Tagua. One $\mathrm{kg}$ of propolis sample was mixed with 5 liters of $60 \%$ ethanol and stirred for $24 \mathrm{~h}$ at $20^{\circ} \mathrm{C}$. After stirring and filtering under vacuum, the filtrate was evaporated to dryness in a Rotavapor. The dry starting material was $1000 \mathrm{~g}$ of propolis. The extraction yield was $450 \mathrm{~g}(45 \%)$. The extract was previously standardized [28] and HPLC analysis showed that it had the following composition: galangin $0.43 \%$; hydroxycinnamic acids (caffeic acid 3.85\%; p-cumaric acid $0.02 \%$, ferulic acid 0.04\%), CAPE $22.30 \%$.

\section{Cell culture and treatments}

KB cells were obtained from American Type Culture Collection (ATCC, Rockville, MD, USA) and were maintained in RPMI supplemented with $10 \%$ fetal calf serum (FCS), $100 \mathrm{U} / \mathrm{ml}$ penicillin, and $100 \mu \mathrm{g} / \mathrm{ml}$ streptomycin. Cells were maintained at $37^{\circ} \mathrm{C}$ under humidified 5\% carbon dioxide to allow cell attachment. Cells were then harvested by trypsinization and differently treated with $80 \mu \mathrm{g} / \mathrm{ml}$ concentration of Chilean propolis ethanolic extract in the presence or absence of $10 \mu \mathrm{M} \mathrm{SnCl} 2$ and $15 \mu \mathrm{M}$ tin-mesoporphirin (SnMP), an inducer and inhibitor of Hmox activity respectively. Even though the ethanolic extract of propolis was dissolved in ethanol, at the treatment stage the final ethanol concentration was never higher than $0.05 \%$. Under these conditions, ethanol was not toxic and did not alter the parameters tested. In order to evaluate the role of $\mathrm{CO}$ in this system, we used tricarbonyldichlororuthenium (II) dimer (CORM-II), a wellknown and characterized CO releasing molecule (26), at different concentrations $(10-40 \mu \mathrm{M})$ and time exposures (24, 48 and $72 \mathrm{~h}$ ). Inactive form of the compound (negative control) was also used in some experiments and it was prepared as follows: CORM-2 was 'inactivated' (iCORM-2) by adding the compound to DMSO and leaving it for $18 \mathrm{~h}$ at $37^{\circ} \mathrm{C}$ in a $5 \% \mathrm{CO}_{2}$ humidified atmosphere to liberate CO. The iCORM-2 solution was finally bubbled with nitrogen to remove the residual $\mathrm{CO}$ present in the solution. This preparation was referred as control in all experiments with this compound. At the end of the treatment cells were scraped, washed with cold phosphate buffered saline (PBS) and immediately processed. The concentration of proteins in the cellular lysate was determined according to the method of Bradford [30].

\section{MTT assay}

Cells were set up $6 \times 10^{3}$ cells per well of a 96 multiwell flatbottomed $200 \mu \mathrm{l}$ microplate. Cells were then incubated at $37^{\circ} \mathrm{C}$ in a humidified $5 \% \mathrm{CO}_{2} / 95 \%$ air mixture. At the end of treatment time, 20 $\mu \mathrm{l}$ of $0.5 \%$ MTT 3(4,5-dimethyl-thiazol-2-yl)2,5-diphenyl-tetrazolium bromide in PBS were added to each microwell. After one hour of incubation with the reagent, the supernatant was removed and replaced with $100 \mu \mathrm{l}$ of DMSO. The optical density of each well sample was measured with a microplate spectrophotometer reader (Digital and Analog Systems, Rome, Italy) at $550 \mathrm{~nm}$.

\section{Lactic dehydrogenase $(\mathrm{LDH})$ release}

Lactic dehydrogenase (LDH) activity was spectrophotometrically measured in the culture medium and in the cellular lysates at $340 \mathrm{~nm}$ by analyzing $\mathrm{NADH}$ reduction during the pyruvate-lactate transformation. Cells were lysed with $50 \mathrm{mM}$ Tris- $\mathrm{HCl}+20 \mathrm{mM}$ EDTA pH $7.4+0.5 \%$ sodium dodecyl sulfate (SDS), further disrupted by sonication and centrifuged at $13,000 \mathrm{~g}$ for $15 \mathrm{~min}$. The assay mixture ( $1 \mathrm{ml}$ final volume) for the enzymatic analysis contained: $33 \mu \mathrm{l}$ of sample (5-10 $\mu \mathrm{g}$ of protein) in $48 \mathrm{mM}$ PBS $\mathrm{pH} 7.5$ plus $1 \mathrm{mM}$ pyruvate and $0.2 \mathrm{mM}$ NADH. The percentage of $\mathrm{LDH}$ released was calculated as percentage of the total amount, considered as the sum of the enzymatic activity present in the cellular lysate and that in the culture medium. A Hitachi U-2000 spectrophotometer (Hitachi, Tokyo, Japan) was used.

\section{Western blotting}

Cell lysate was collected for Western blot analysis and protein levels were visualized by immunoblotting with antibodies against Hmoxl, Hmox-2 or p21 as previously described [31]. Briefly, $30 \mu \mathrm{g}$ of lysate supernatant were separated by SDS/polyacrylamide gel electrophoresis and transferred to a nitrocellulose membrane. The membranes were incubated overnight with $5 \%$ milk in $10 \mathrm{mM}$ Tris- $\mathrm{HCl}(\mathrm{pH} 7.4), 150$ $\mathrm{mM} \mathrm{NaCl}, 0.05 \%$ Tween 20 (TBST) buffer at $4^{\circ} \mathrm{C}$. After washing with TBST, the membranes were incubated with a 1:1000 dilution of antiHmox1, anti-Hmox-2 or p21 antibody for 1 hour at room temperature with constant shaking. The filters were then washed and subsequently 
probed with horseradish peroxidase-conjugated anti-mouse IgG (Amersham) for Hmox1 and p21 at a dilution of 1:2000, or horseradish peroxidase-conjugated anti-rabbit IgG (Amersham) for Hmox-2 at a dilution of 1:5000. The used Hmoxl antibody recognizes the full length $(32 \mathrm{Kda})$ form of the protein which possesses the complete enzymatic activity. Actin was also used for normalization. Chemiluminescence detection was performed using an ECL detection kit according to the manufacturer's instructions.

\section{ROS determination}

ROS determination was performed by using a fluorescent probe 2', 7'-dichlorofluorescein diacetate (DCFH-DA), as previously described [32]. DCFH-DA diffuses through the cell membrane, it is enzymatically hydrolyzed by intracellular esterases and oxidized to the fluorescent 2',7'-dichlorofluorescein (DCF) in the presence of ROS. The intensity of fluorescence is proportional to the levels of intracellular oxidant species. One hundred microliters of 100

M DCFH-DA, dissolved in $100 \%$ methanol was added to the cellular medium where the acetate group is not hydrolysed [32], and the cells were incubated at $37^{\circ} \mathrm{C}$ for $30 \mathrm{~min}$. After incubation, $\mathrm{KB}$ cells were lysated and centrifuged at $10,000 \mathrm{~g}$ for $10 \mathrm{~min}$. The fluorescence (corresponding to the radical species-oxidized 2', 7'dichlorofluorescein, DCF) was monitored spectrofluorometrically using a Hitachi F-2000 spectrofluorimeter (Hitachi, Tokyo, Japan): excitation $488 \mathrm{~nm}$, emission $525 \mathrm{~nm}$. The total protein content was evaluated for each sample, so the results are reported as Fluorescence Intensity/mg protein and compared to relative control.

\section{Heme oxygenase activity assay}

Briefly, microsomes from harvested cells were added to a reaction mixture containing NADPH $(0.8 \mathrm{~mm})$, glucose 6-phosphate $(2 \mathrm{~mm})$, glucose-6-phosphate dehydrogenase ( 0.2 units), $3 \mathrm{mg}$ of rat liver cytosol prepared from a $105,000 \times \mathrm{g}$ supernatant fraction as a source of biliverdin reductase, potassium phosphate buffer (PBS, $100 \mathrm{~mm}, \mathrm{pH}$ 7.4), $\mathrm{MgCl} 2(0.2 \mathrm{~mm})$, and hemin $(20 \mu \mathrm{m})$. The reaction was conducted at $37^{\circ} \mathrm{C}$ in the dark for $1 \mathrm{~h}$ and terminated by the addition of $1 \mathrm{ml}$ of chloroform, and the extracted bilirubin was calculated by the difference in absorbance between 464 and $530 \mathrm{~nm}(\varepsilon=40 \mathrm{~mm}-1$ $\mathrm{cm}-1$ ). Heme oxygenase activity was expressed as picomoles of bilirubin/mg of cell protein/h.

\section{Statistical analysis}

One-way analysis of variance (ANOVA) followed by Bonferroni's $t$ test was performed in order to estimate significant differences among groups. Each value represents the mean \pm SD of three separate experiments performed in duplicate and differences between groups were considered to be significant at $\mathrm{p}<0.005$.

\section{Results}

\section{Effects of Chilean propolis on $\mathrm{KB}$ cells viability}

The effects of Chilean propolis extract on KB cell viability following treatment with different concentrations and time exposures are shown in Figure 1A. Treatment of cell cultures for 24, 48 and $72 \mathrm{~h}$ with propolis $(80 \mu \mathrm{g} / \mathrm{ml})$ containing high concentration of CAPE, a wellknown inducer of Hmoxl expression and activity (35), resulted in a time-dependent decrease in viability $(\mathrm{p}<0.001)$. Similar results were obtained by using $\mathrm{SnCl}_{2}(10 \mu \mathrm{M})$, also a well-known inducer of Hmoxl protein expression and activity [19]. In addition, the combination of both propolis and $\mathrm{SnCl}_{2}$ showed a decreased viability when compared to propolis or $\mathrm{SnCl}_{2}$ alone $(\mathrm{p}<0.001)$. Interestingly, the addition of SnMP, a potent inhibitor of Hmox1 activity (6), significantly increased viability in propolis or propolis plus $\mathrm{SnCl}_{2}$ treated cultures $(\mathrm{p}<0.001)$. The exposure of cell culture to SnMP alone did not show any significant changes in cell viability when compared to control. We also tested the effects of CORM-II at different concentrations and time exposures, observing a dramatic dose and time dependent decrease in viability, which suggests that KB cells are particularly sensitive to $\mathrm{CO}$ when compared to non tumoral cell types [10] (Figure 1B). Concentrations of both propolis and $\mathrm{SnCl}_{2}$, not toxic for normal cell types, derive from our preliminary experiments (unpublished results) where they showed maximal biological effect.

A

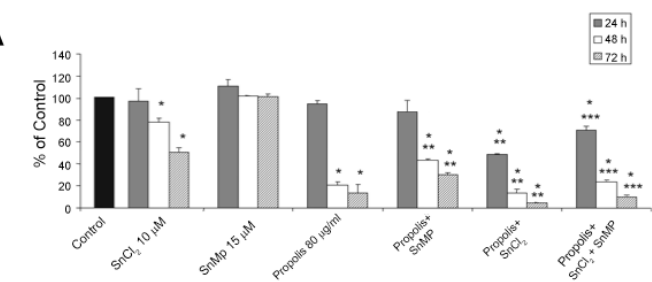

B

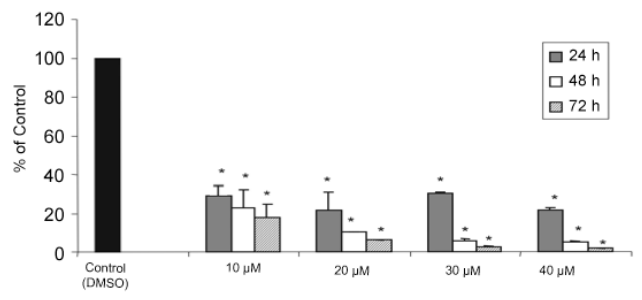

Figure 1. Viability of $\mathrm{KB}$ cells treated at different time exposures (24, 48 and $72 \mathrm{~h}$ ). (A) Cells were treated with Chilean propolis ethanolic extract $(80 \mu \mathrm{g} / \mathrm{ml})$ in the presence or absence of $10 \mu \mathrm{M}$ $\mathrm{SnCl}_{2}$ or $15 \mu \mathrm{M}$ SnMP. (B) Cells were treated with different concentrations $(5-50 \mu \mathrm{M})$ of tricarbonyldichlororuthenium (II) dimer (CORM-II). Each value represents the mean \pm SD of three separate experiments performed in duplicate. $\left({ }^{*} \mathrm{p}<0.001\right.$ vs. Control; ${ }^{* *} \mathrm{p}<0.001$ vs. Propolis; ${ }^{* *} \mathrm{p}<0.001$ vs. Propolis $+\mathrm{SnCl}_{2}$ ).

\section{LDH release determination}

$\mathrm{LDH}$ release was also measured to evaluate the presence of cell necrosis as a result of cell disruption subsequent to membrane rupture (Figure 2). Under our experimental conditions, treatment of cell cultures with propolis resulted in a significant increase in $\mathrm{LDH}$ release $(\mathrm{p}<0.001)$ at $72 \mathrm{~h}$. Surprisingly, $\mathrm{SnCl}_{2}$ treatment did not result in a significant release of $\mathrm{LDH}$, thus indicating that a different mechanism, such as cell cycle arrest, may occur in $\mathrm{SnCl}_{2}$ mediated cytotoxicity. Furthermore, propolis plus $\mathrm{SnCl}_{2}$ treated cultures showed a significant increase in $\mathrm{LDH}$ release when compared to propolis or $\mathrm{SnCl}_{2}$ alone and this effect was abolished by the addition of SnMP, thus suggesting that induction of Hmox activity renders KB cells more susceptible to propolis mediated cell necrosis. 


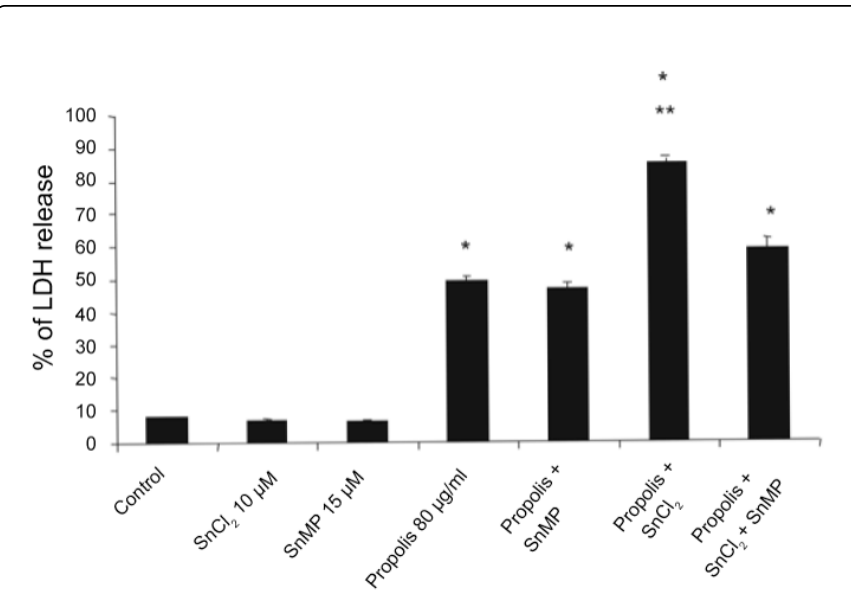

Figure 2. $\mathrm{LDH}$ released in $\mathrm{KB}$ cells untreated and treated for $72 \mathrm{~h}$ with Chilean propolis ethanolic extract $(80 \mu \mathrm{g} / \mathrm{ml})$ in the presence or absence of $10 \mu \mathrm{M} \mathrm{SnCl} 2$ or $15 \mu \mathrm{M}$ SnMP. Each value represents the mean $\pm \mathrm{SD}$ of three separate experiments performed in duplicate. $\left({ }^{\star} \mathrm{p}<0.001\right.$ vs. Control; ${ }^{* *} \mathrm{p}<0.001$ vs. Propolis).

\section{Western Blot analysis}

Cells were examined for the levels of Hmoxl and Hmox-2 proteins by Western blot analysis. The results of three representative experiments are reported in Figure 3A. Cells showed basal levels of Hmoxl protein and a significant increase after treatment with propolis and $\mathrm{SnCl}_{2}$ as compared to untreated cells (Figure $3 \mathrm{~A}$ and $3 \mathrm{~B}$ ). No significant effects were observed on Hmox-2 protein levels after pharmacological treatments (Figure $3 \mathrm{~A}$ and 3B). SnMP, a transcriptional activator of Hmoxl gene and inhibitor of Hmox activity, did not change Hmoxl protein expression in propolis or $\mathrm{SnCl}_{2}$ treated cultures (data not shown) thus confirming our previous studies $[1,16,17]$.

In order to further elucidate the molecular mechanism leading to decreased cell viability, we also examined the expression of $\mathrm{p} 21$, a wellknown inhibitor of cell cycle progression. The addition of $\mathrm{SnCl}_{2}$ to the culture medium resulted in a significant increase of $\mathrm{p} 21$ protein expression (Figure 3A, 3B and 3C). By contrast, propolis was not able to induce p21 protein, thus suggesting that propolis mediated cell number decrease may be related to necrotic cell death. In order to establish a link between Hmox1 derived $\mathrm{CO}$ and $\mathrm{p} 21$ expression in $\mathrm{KB}$ cells, we determined the expression of p21 following CORM-II treatment at different concentrations (Figure 3D and 3E). This set of experiments showed a marked increase of p21 expression following treatment with 10 and $20 \mu \mathrm{M}$ concentrations whereas higher concentrations did not show any significant effects, suggesting that low $\mathrm{CO}$ levels regulate $\mathrm{KB}$ cell proliferation via $\mathrm{p} 21$ upregulation, but higher concentrations are toxic. Of note is the fact that the same concentrations of CORM-II did not show any significant toxicity on other not tumoral cells such as endothelial cells, and astroglial cells (data not shown) and cardiomyocytes [33], thus further suggesting that $\mathrm{KB}$ cells are particularly sensitive to $\mathrm{CO}$.

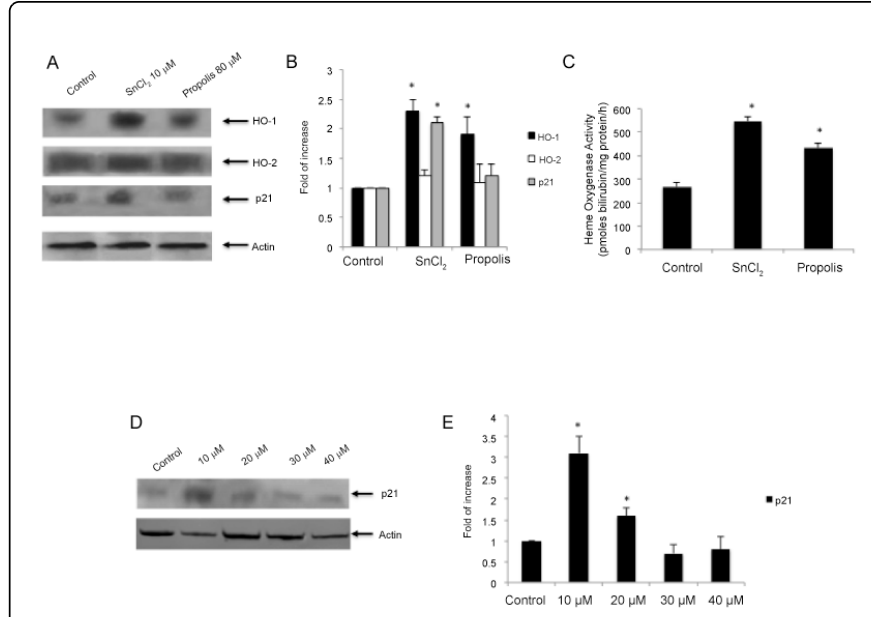

Figure 3. (A) Western Blot analysis of Hmox1, Hmox-2 and p21 following treatments for $72 \mathrm{~h}$ with Chilean propolis ethanolic extract $(80 \mu \mathrm{g} / \mathrm{ml})$ and $10 \mu \mathrm{M} \mathrm{SnCl}_{2}$. (B) Densitometric analysis of western Blot following actin normalization. (C) Hmox activity following different pharmacological treatment. (D) p21 protein expression following treatments with tricarbonyldichlororuthenium (II) dimer (CORM-II) at different concentrations $(5-50 \mu \mathrm{M})$. (E) Blots shown are representative of Western blot analysis from three separate experiments $\left({ }^{*} \mathrm{p}<0.001\right.$ vs control).

\section{ROS determination}

ROS were determined using a fluorescent probe DCFH-DA. The probe diffuses into the cells, intracellular esterases hydrolyze the acetate groups, and the resulting 2', $7^{\prime}$-dichlorofluorescin (DCFH) then reacts with intracellular oxidants resulting in the observed fluorescence. The intensity of fluorescence is proportional to the levels of intracellular oxidant species. As shown in Figure 4, the addition of propolis or $\mathrm{SnCl}_{2}$ for $72 \mathrm{~h}$ resulted in a significant decrease in $\mathrm{ROS}$ formation when compared to control. This effect was reversed, in part, by the addition of SnMP, thus suggesting that the phenolic components of propolis per se play a key role in the anti-oxidant properties of propolis.

\section{Discussion}

There is increasing evidence for an association between a high consumption of fruit and vegetables and reduced risk of oral cancer, suggesting that natural products offer a protective effect against oral cancer $[34,35]$. In addition many substances derived from dietary or medicinal plants are known to be effective and versatile chemopreventive and antitumoral agents in a number of experimental models of carcinogenesis [36]. In this regard, Li et al. [37] showed that curcumin, a natural Hmoxl inducer, present in turmeric and curry and possessing antioxidant properties, appeared to have an inhibitory effect on the progression from dysplasia to SCC.

We describe, in the present study, the effects of pharmacological induction of Hmoxl using Chilean propolis and $\mathrm{SnCl}_{2}$ in $\mathrm{KB}$ cells, and how this may impact on $\mathrm{KB}$ cell cytotoxicity and proliferation. We demonstrated that Chilean propolis and $\mathrm{SnCl}_{2}$ showed a significant increase in Hmoxl protein expression which was followed by a 
decrease in cell viability and this effect was reversed by the addition of SnMP, thus suggesting that Hmox1 may play an important role in both propolis and $\mathrm{SnCl}_{2}$ toxicity. These results are consistent with our previous results showing that $\mathrm{KB}$ cells are particularly sensitive to propolis [28]. The possible involvement of the Hmox system was further suggested by the use of CORM-II which showed that, CO, one of the Hmox products, is toxic for $\mathrm{KB}$ cells in a dose- and timedependent manner. We also propose that propolis has different mechanisms of toxicity in $\mathrm{KB}$ cells. In fact, we found that this compound caused a significant decrease in cell number as a result of cell necrosis as measured by $\mathrm{LDH}$ release. By contrast, $\mathrm{SnCl}_{2}$ showed a significant decrease in cell number unaccompanied by a concomitant cell membrane breakdown. In this case, decreased cell number may be related to the increased expression of Hmoxl which leads to increased $\mathrm{CO}$ cellular levels, thus upregulating p21 protein expression. This hypothesis is supported by our experiments with CORM-II, which showed that increased CO levels result in a significant increase in p21 protein expression. These results are in apparent contrast with our recent work showing that the same concentrations of CO releasing molecule resulted in a significant increase of endothelial cell proliferation and angiogenesis, as measured by capillary formation; however high concentrations of $\mathrm{CO}$ releasing molecule resulted toxic for endothelial cells and inhibited angiogenesis [38]. These data obtained on different cell types suggest that $\mathrm{CO}$ regulates cell proliferation in a cell-specific, dose- and time-dependent manner. In addition, these results are consistent with our previous work [39] demonstrating that Hmoxl regulates proliferation in a cell-specific manner by differentially regulating $\mathrm{p} 21$ protein expression; in fact, pharmacological Hmox1 induction increased endothelial cell proliferation, but inhibited smooth muscle cell proliferation. Furthermore, we and others demonstrated that the same CORM-II concentrations showed no significant cytotoxic effects in other cell types such as astrocytes, endothelial cells, smooth muscle cells and cardiomyocyte $[33,38,40]$.

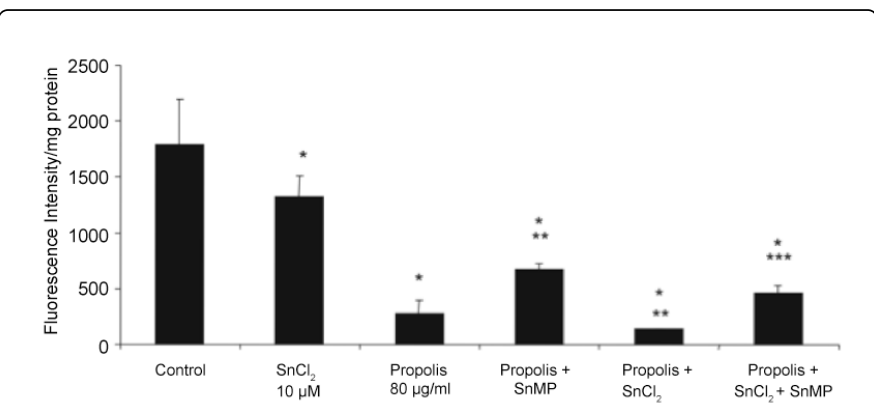

Figure 4. Intracellular ROS formation in $\mathrm{KB}$ cells untreated and treated with Chilean propolis ethanolic extract $(80 \mu \mathrm{g} / \mathrm{ml})$ for 72 hours in the presence or absence of $10 \mu \mathrm{M} \mathrm{SnCl}_{2}$ or $15 \mu \mathrm{M}$ SnMP. Each value represents the mean \pm SD of three separate experiments performed in duplicate. $\left({ }^{*} \mathrm{p}<0.001\right.$ vs. Control; ${ }^{* *} \mathrm{p}<0.001$ vs. Propolis; ${ }^{* *} \mathrm{p}<0.001$ vs. Propolis $+\mathrm{SnCl}_{2}$ ).

The idea of the involvement of different mechanisms in propolis toxicity, besides Hmoxl induction, is supported also from our ROS formation data showing that propolis, because of its anti-oxidant extract phenolic components activity (galangin, caffeic acid, p-cumaric acid, ferulic acid and CAPE) [22], resulted in a dramatic reduction in the formation of ROS, a mechanism involved in cancer cell proliferation [41]. This hypothesis is supported also by previous studies showing that phenolic phytochemicals may scavenge the constitutively high amounts of ROS in cancer cells, thereby blocking MAPK signaling, activation of NFkB and AP-1, and ultimately the expression of responsive genes that stimulate cancer cell proliferation [26].

The addition of SnMP, significantly attenuated the anti-oxidant effects of propolis, even though ROS remained significantly low when compared to control, thus confirming that the anti-oxidant properties of this compound are mediated in part by Hmoxl induction and also by the phenolic structure of propolis components. These data are also confirmed by our observations showing that $\mathrm{SnCl}_{2}$ caused a significant decrease in ROS formation eventhough propolis was a more potent ROS scavenger.

Taken all together, our data indicates that $\mathrm{KB}$ cells seem to be particularly vulnerable to Hmoxl induction which may represent a mechanism by which these cells regulate their proliferation and cell cycle progression, thus suggesting that the Hmox system may be the Achille's heel of KB cells. In fact, pharmacological induction of Hmox1 is associated with decreased cell proliferation following p21 upregulation and increased cytotoxicity. These effects seem to be mediated by Hmox derived CO as suggested by the results following CORM-II treatment. Furthermore, other minor sources of CO include the auto-oxidation [42] of phytochemical phenols which may account, in part, for propolis mediated cytotoxicity. These in vitro results seem to be consistent with recent clinical findings showing that increased Hmoxl expression was associated with reduced lymph node metastasis in patients affected by oral SCC [5]. These results together with our recent data on angiogenesis strongly suggest that CO may represent an excellent strategy for controlling cancer growth.

In conclusion, our studies demonstrate that Chilean propolis, due to its phenolic components, and $\mathrm{SnCl}_{2}$ not only have cytotoxic and antiproliferative effects in $\mathrm{KB}$ cells, but also utilize Hmox1 in exerting their antitumoral effects, thus providing a new and powerful strategy for oral SCC treatments.

\section{Acknowledgement}

The authors would like to thank Dr. Mike Wilkinson for proofreading the manuscript. This work was financially supported by a grant (ex 60\%) from MURST (Ministero dell' Universita' e della Ricerca Scientifica e Tecnologica), Rome, Italy.

\section{References}

1. Pisani P, Parkin DM, Bray F, Ferlay J (1999) Estimates of the worldwide mortality from 25 cancers in 1990. Int J Cancer 83: 18-29.

2. Johnson N (2001) Tobacco use and oral cancer: a global perspective. J Dent Educ 65: 328-339.

3. Zavras AI, Douglass CW, Joshipura K, Wu T, Laskaris G, et al. (2001) Smoking and alcohol in the etiology of oral cancer: gender-specific risk profiles in the south of Greece. Oral Oncol 37: 28-35.

4. Xie X, Clausen OP, Boysen M (2002) Prognostic significance of p21WAF1/CIP1 expression in tongue squamous cell carcinomas. Arch Otolaryngol Head Neck Surg 128: 897-902.

5. Yanagawa T, Omura K, Harada H, Nakaso K, Iwasa S, et al. (2004) Heme oxygenase-1 expression predicts cervical lymph node metastasis of tongue squamous cell carcinomas. Oral Oncol 40: 21-27.

6. Goodman AI, Choudhury M, da Silva JL, Schwartzman ML, Abraham NG (1997) Overexpression of the heme oxygenase gene in renal cell carcinoma. Proc Soc Exp Biol Med 214: 54-61. 
7. Schacter BA, Kurz P (1986) Alterations in microsomal drug metabolism and heme oxygenase activity in isolated hepatic parenchymal and sinusoidal cells in Murphy-Sturm lymphosarcoma-bearing rats. Clin Invest Med 9: 150-155.

8. Maines MD, Abrahamsson PA (1996) Expression of heme oxygenase-1 (HSP32) in human prostate: normal, hyperplastic, and tumor tissue distribution. Urology 47: 727-733.

9. Matsumoto A, Hanayama R, Nakamura M, Suzuki K, Fujii J, et al. (1998) A high expression of heme oxygenase- 1 in the liver of LEC rats at the stage of hepatoma: the possible implication of induction in uninvolved tissue. Free Radic Res 28: 383-391

10. Nishie A, Ono M, Shono T, Fukushi J, Otsubo M, et al. (1999) Macrophage infiltration and heme oxygenase-1 expression correlate with angiogenesis in human gliomas. Clin Cancer Res 5: 1107-1113.

11. Sunamura M, Duda DG, Ghattas MH, Lozonschi L, Motoi F, et al. (2003) Heme oxygenase-1 accelerates tumor angiogenesis of human pancreatic cancer. Angiogenesis 6: 15-24.

12. Barbagallo I, Galvano F, Frigiola A, Cappello F, Riccioni G, et al. (2013) Potential therapeutic effects of natural heme oxygenase-1 inducers in cardiovascular diseases. Antioxid Redox Signal 18: 507-521.

13. McCoubrey WK Jr, Ewing JF, Maines MD (1992) Human heme oxygenase-2: characterization and expression of a full-length cDNA and evidence suggesting that the two HO-2 transcripts may differ by choice of polyadenylation signal. Arch Biochem Biophys 295: 13-20.

14. Shibahara S, Yoshizawa M, Suzuki H, Takeda K, Meguro K, et al. (1993) Functional analysis of cDNAs for two types of human heme oxygenase and evidence for their separate regulation. J Biochem 113: 214-218.

15. Li Volti G, Sacerdoti D, Di Giacomo C, Barcellona ML, Scacco A, et al (2008) Natural heme oxygenase-1 inducers in hepatobiliary function. World J Gastroenterol 14: 6122-6132.

16. Foresti R, Hoque M, Monti D, Green CJ, Motterlini R (2005) Differential activation of heme oxygenase-1 by chalcones and rosolic acid in endothelial cells. J Pharmacol Exp Ther 312: 686-693.

17. Scapagnini G, Foresti R, Calabrese V, Giuffrida Stella AM, Green CJ, et al. (2002) Caffeic acid phenethyl ester and curcumin: a novel class of heme oxygenase-1 inducers. Mol Pharmacol 61: 554-561.

18. Acquaviva R, Campisi A, Raciti G, Avola R, Barcellona ML, et al. (2005) Propofol inhibits caspase- 3 in astroglial cells: role of heme oxygenase-1. Curr Neurovasc Res 2: 141-148.

19. Li Volti G, Sorrenti V, Murabito P, Galvano F, Veroux M, et al. (2007) Pharmacological induction of heme oxygenase-1 inhibits iNOS and oxidative stress in renal ischemia-reperfusion injury. Transplant Proc 39: 2986-2991.

20. Li Volti G, Zappalà A, Leggio GM, Mazzola C, Drago F, et al. (2011) Tin chloride enhances parvalbumin-positive interneuron survival by modulating heme metabolism in a model of cerebral ischemia. Neurosci Lett 492: 33-38.

21. Burdock GA (1998) Review of the biological properties and toxicity of bee propolis (propolis). Food Chem Toxicol 36: 347-363.

22. Russo A, Longo R, Vanella A (2002) Antioxidant activity of propolis: role of caffeic acid phenethyl ester and galangin. Fitoterapia 73 Suppl 1: S21-29.

23. Scifo C, Cardile V, Russo A, Consoli R, Vancheri C, et al. (2004) Resveratrol and propolis as necrosis or apoptosis inducers in human prostate carcinoma cells. Oncol Res 14: 415-426.

24. Cardile V, Panico A, Gentile B, Borrelli F, Russo A (2003) Effect of propolis on human cartilage and chondrocytes. Life Sci 73: 1027-1035.

25. Nagaoka T, Banskota AH, Tezuka Y, Saiki I, Kadota S (2002) Selective antiproliferative activity of caffeic acid phenethyl ester analogues on highly liver-metastatic murine colon 26-L5 carcinoma cell line. Bioorg Med Chem 10:3351-3359.

26. Loo G (2003) Redox-sensitive mechanisms of phytochemical-mediated inhibition of cancer cell proliferation (review). J Nutr Biochem 14: 64-73.

27. Acquaviva R, Campisi A, Murabito P, Raciti G, Avola R, et al. (2004) Propofol attenuates peroxynitrite-mediated DNA damage and apoptosis in cultured astrocytes: an alternative protective mechanism. Anesthesiology 101: 1363-1371.

28. Russo A, Cardile V, Sanchez F, Troncoso N, Vanella A, et al. (2004) Chilean propolis: antioxidant activity and antiproliferative action in human tumor cell lines. Life Sci 76: 545-558.

29. Lee YJ1, Liao PH, Chen WK, Yang CY (2000) Preferential cytotoxicity of caffeic acid phenethyl ester analogues on oral cancer cells. Cancer Lett 153: 51-56.

30. Bradford MM (1976) A rapid and sensitive method for the quantitation of microgram quantities of protein utilizing the principle of protein-dye binding. Anal Biochem 72: 248-254.

31. Campisi A, Caccamo D, Li Volti G, Currò M, Parisi G, et al. (2004) Glutamate-evoked redox state alterations are involved in tissue transglutaminase upregulation in primary astrocyte cultures. FEBS Lett 578: 80-84.

32. Hempel SL, Buettner GR, O'Malley YQ, Wessels DA, Flaherty DM (1999) Dihydrofluorescein diacetate is superior for detecting intracellular oxidants: comparison with 2',7'-dichlorodihydrofluorescein diacetate, 5(and 6)-carboxy-2',7'-dichlorodihydrofluorescein diacetate, and dihydrorhodamine 123. Free Radic Biol Med 27:146-159.

33. Hu CM,Chen YH, Chiang MT, Chau LY (2004) Heme oxygenase-1 inhibits angiotensin II-induced cardiac hypertrophy in vitro and in vivo. Circulation 110: 309-316.

34. La Vecchia C, Tavani A, Franceschi S, Levi F, Corrao G, et al. (1997) Epidemiology and prevention of oral cancer. Oral Oncol 33: 302-312.

35. Morse DE, Pendrys DG, Katz RV, Holford TR, Krutchkoff DJ, et al. (2000) Food group intake and the risk of oral epithelial dysplasia in a United States population. Cancer Causes Control 11: 713-720.

36. Yanaida Y, Kohno H, Yoshida K, Hirose Y, Yamada Y, et al. (2002) Dietary silymarin suppresses 4-nitroquinoline 1-oxide-induced tongue carcinogenesis in male F344 rats. Carcinogenesis 23: 787-794.

37. Li N, Chen X, Liao J, Yang G, Wang S, et al. (2002) Inhibition of 7,12dimethylbenz[a]anthracene (DMBA)-induced oral carcinogenesis in hamsters by tea and curcumin. Carcinogenesis 23: 1307-1313.

38. Li Volti G, Sacerdoti D, Sangras B, Vanella A, Mezentsev A, et al. (2005) Carbon monoxide signaling in promoting angiogenesis in human microvessel endothelial cells. Antioxid Redox Signal 7: 704-710.

39. Li Volti G, Wang J, Traganos F, Kappas A, Abraham NG (2002) Differential effect of heme oxygenase-1 in endothelial and smooth muscle cell cycle progression. Biochem Biophys Res Commun 296: 1077-1082.

40. Motterlini R, Clark JE, Foresti R, Sarathchandra P, Mann BE, et al. (2002) Carbon monoxide-releasing molecules: characterization of biochemical and vascular activities. Circ Res 90: E17-24.

41. Lee KG, Shibamoto T, Takeoka GR, Lee SE, Kim JH, et al. (2003) Inhibitory effects of plant-derived flavonoids and phenolic acids on malonaldehyde formation from ethyl arachidonate. J Agric Food Chem 51: 7203-7207.

42. Rodgers PA, Vreman HJ, Dennery PA, Stevenson DK (1994) Sources of carbon monoxide $(\mathrm{CO})$ in biological systems and applications of $\mathrm{CO}$ detection technologies. Semin Perinatol 18: 2-10.
This article was originally published in a special issue, entitled: "Anticancer Drugs", Edited by Philippe Becuwe,Henri Poincaré's University of Nancy,France 